\title{
Mutation in PITX2 is associated with ring dermoid of the cornea
}

\author{
K Xia, L Wu, X Liu, X Xi, D Liang, D Zheng, F Cai, Q Pan, Z Long, H Dai, Z Hu, B Tang, Z Zhang, \\ J Xia
}

J Med Genet 2004;41:e129 (http://www.jmedgenet.com/cgi/content/full/41/12/e129). doi: 10.1136/jmg.2004.022434

$\mathrm{R}$ ing dermoid of the cornea (RDC, MIMl80550) is an autosomal dominantly inherited syndrome characterised by bilateral annular limbal dermoids with corneal and conjunctival extension. The genetic basis of RDC is unknown. We report linkage of chromosome 4q24q26 to RDC and identification of a missense mutation in PITX2 in 17 disease affected individuals but not in eight genetically related normal individuals in a large Chinese family.

\section{METHODS}

A large Chinese family with 17 individuals affected by the RDC was identified (figs $\mathrm{l}$ and 2). All patients were diagnosed by the same physician (XHX). Informed written consent for blood sample collection was obtained from all participants.

Linkage analysis and genotyping were done essentially as previously described. ${ }^{1}$ Genome-wide screening was carried out with 382 microsatellite markers covering all autosomal chromosomes, with an average interval of $10 \mathrm{cM}$ (ABI PRISM $^{\mathrm{TM}}$ linkage mapping set, version 2.0). Fine mapping was accomplished using fluorescent labelled primers from the Marshfield database. Alleles were analysed by GeneScan analysis, version 3.0 software, and Genotyper, version 2.1 software (ABI PRISM ${ }^{\mathrm{TM}}$ linkage analysis and haplotype

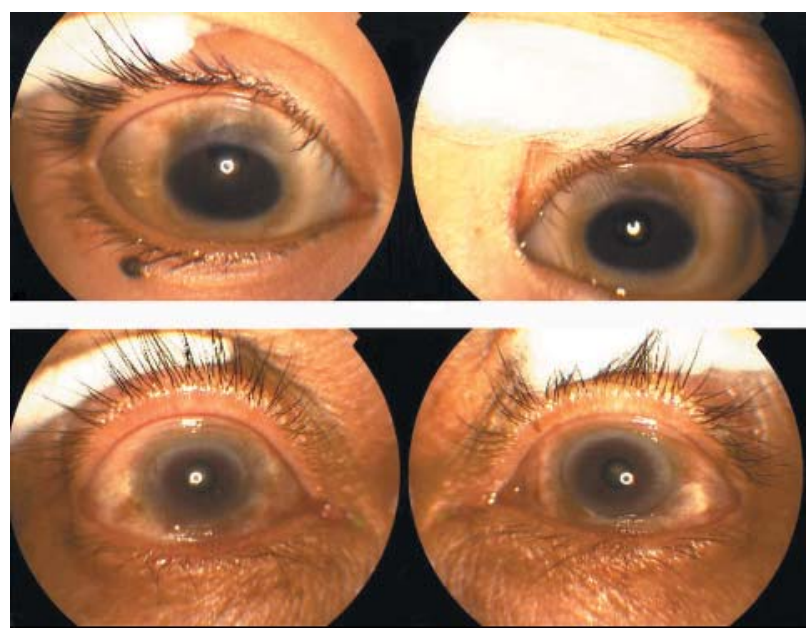

Figure 1 Eyes affected by ring dermoid of the cornea (RDC) in two patients, II-2 (upper panel) and IV-3 (lower panel). Yellow-white tumourlike apophyses are visible on the corneal border of both eyes. The apophyses are diffuse in the superficial layer of the cornea and conjunctiva. The corneal border is not clear and the diameter of the transparent region of cornea is diminished to about 7-8 $\mathrm{mm}$. The upward shift of the right pupil of IV-3 is caused by cataract resection (the affected individual, IV-3, also has bilateral glaucoma and congenital cataracts in the right eye).

\section{Key points}

- The ring dermoid of the cornea (RDC, MIM180550) is an autosomal dominantly inherited syndrome characterised by bilateral annular limbal dermoids with corneal and conjunctival extension.

- We report linkage of a $15 \mathrm{cM}$ interval on chromosome 4q24-q26 to RDC. A missense mutation in PITX2 was found in 17 disease affected individuals but not in eight genetically related normal individuals in a large Chinese family, and in 157 normal unrelated individuals.

- Given that PITX2 functions in eye development, these findings suggest mutations in PITX2 as a potential cause of RDC.

construction). Two point linkage analysis was conducted using the MLINK program of the Linkage 5.1 package (Rockefeller University, New York, USA). The disease allele frequency was set at 0.0001 with the recombination fraction $(\theta)$ in male and female subjects considered equal. The penetrance frequency of the disease was assumed to be 0.99 with autosomal dominance. The most likely haplotype was constructed by the Cyrillic program (Electrotechnical Laboratory, Tokyo, Japan).

For mutation analysis, all exons and intron-exon boundaries of selected genes were amplified by polymerase chain reaction (PCR) using genomic DNA of the proband as template and primers designed according to the genomic sequences obtained from Genbank. Sequencing of the PCR products was automated ( $\mathrm{ABI} 3100$ sequencer).

\section{RESULTS}

In this large Chinese family, 21 of 36 genetically linked individuals were affected by RDC. ${ }^{2}$ Patients showed yellowwhite tumour-like apophyses $(2-3 \mathrm{~mm}$ high and $3-5 \mathrm{~mm}$ wide) on the corneal border of both eyes (fig 1). The apophyses were clinically detectable at birth and progressively impaired the patients' vision with aging. Some affected individuals also had glaucoma (II-2, III-4, and IV-3), unilateral cataracts (IV-3), or involuntary oscillation of the eyes (IV-3). The only clinical manifestation in the affected individuals were in the eyes. Consistent with previously reported autosomal dominantly inherited patterns of RDC, affected cases were found in both male and female descendants of each of four generations.

The linkage analysis was carried out with samples collected from 17 affected individuals, eight genetically related normal

Abbreviations: RDC, ring dermoid of the cornea 


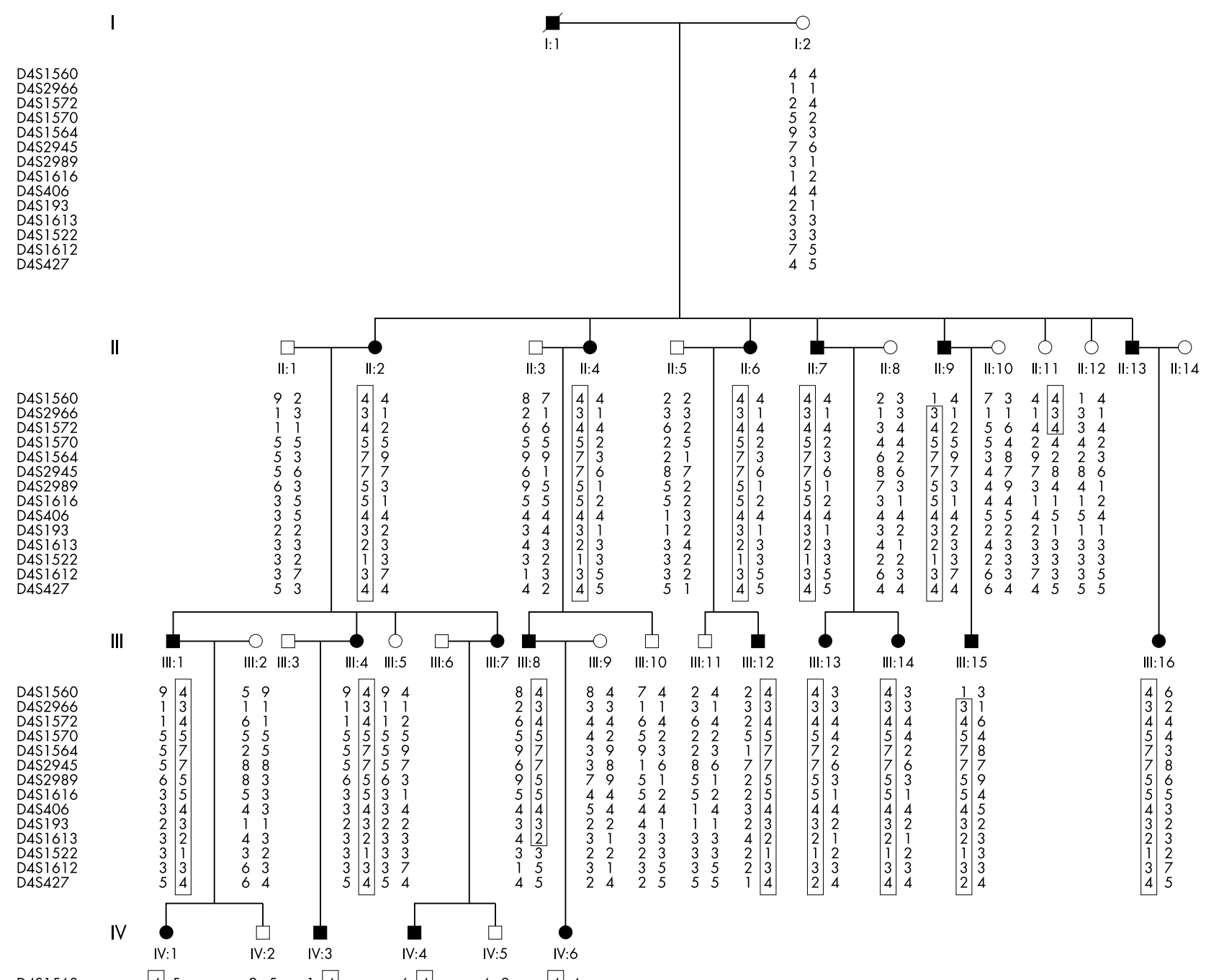

\begin{tabular}{|c|c|c|c|c|c|c|c|c|c|c|}
\hline $\begin{array}{l}\text { D4S } 1560 \\
\text { D4S2966 } \\
\text { D4S } 1572 \\
\text { D4S } 1570 \\
\text { D4S1564 } \\
\text { D4S2945 } \\
\text { D4S2989 } \\
\text { D4S1616 } \\
\text { D4S406 } \\
\text { D4S } 193 \\
\text { D4S 1613 } \\
\text { D4S 1522 } \\
\text { D4S 1612 } \\
\text { D4S427 }\end{array}$ & \begin{tabular}{|l|}
4 \\
3 \\
4 \\
5 \\
7 \\
7 \\
5 \\
5 \\
4 \\
3 \\
2 \\
1 \\
3 \\
4
\end{tabular} & $\begin{array}{l}5 \\
1 \\
6 \\
5 \\
2 \\
8 \\
8 \\
5 \\
4 \\
1 \\
4 \\
3 \\
6 \\
6\end{array}$ & $\begin{array}{ll}9 & 5 \\
1 & 1 \\
1 & 6 \\
5 & 5 \\
5 & 2 \\
5 & 8 \\
6 & 8 \\
3 & 5 \\
3 & 4 \\
2 & 1 \\
3 & 4 \\
1 & 3 \\
3 & 6 \\
4 & 6\end{array}$ & $\begin{array}{l}1 \\
1 \\
1 \\
3 \\
4 \\
6 \\
1 \\
2 \\
3 \\
2 \\
2 \\
2 \\
2 \\
1\end{array}$ & \begin{tabular}{|l|}
4 \\
3 \\
4 \\
5 \\
7 \\
7 \\
5 \\
5 \\
4 \\
3 \\
2 \\
1 \\
3 \\
4
\end{tabular} & $\begin{array}{l}6 \\
1 \\
4 \\
1 \\
3 \\
2 \\
2 \\
5 \\
2 \\
1 \\
1 \\
3 \\
4 \\
3\end{array}$ & \begin{tabular}{|l|}
4 \\
3 \\
4 \\
5 \\
7 \\
7 \\
5 \\
5 \\
4 \\
3 \\
2 \\
1 \\
3 \\
4 \\
\end{tabular} & $\begin{array}{l}4 \\
2 \\
2 \\
5 \\
9 \\
5 \\
4 \\
2 \\
4 \\
3 \\
3 \\
2 \\
1 \\
1\end{array}$ & $\begin{array}{l}2 \\
3\end{array}$ & \begin{tabular}{|l|}
4 \\
3 \\
4 \\
5 \\
7 \\
7 \\
5 \\
5 \\
4 \\
3 \\
2 \\
3 \\
5 \\
5
\end{tabular} \\
\hline
\end{tabular}

Figure 2 Recombination analysis of the family with ring dermoid of the cornea (RDC). Pedigree of the family affected by RDC and haplotype analysis for 14 markers on $4 \mathrm{q} 22$-q26. Markers (from top to bottom) are centromere-D4S1560-D4S2966-D4S1572-D4S1570-D4S1564-

D4S2945-D4S2989-D4S1616-D4S406-D4S193-D4S1613-D4S1522-

D4S1612-D4S427-telomere. The haplotype co-segregating with the

disorder is boxed.

siblings, and seven genetically unrelated family members. Results showed a maximum two point lod score of 3.91 $(\theta=0), 2.33(\theta=0)$, and $1.87(\theta=1)$ for D4S1572, D4S406, and D4S402, respectively. The results establish a linkage of RDC to chromosome 4q. Fine mapping using 12 microsatellite markers around D4S1572 and D4S406 identified a maximum two point lod score of $6.72(\theta=0)$ for D4S2989. The lod scores for the neighbouring markers D4S2945 and D4S161 were 5.04 and $5.01(\theta=0)$, respectively (table 1 ). Haplotype analysis for 14 markers on chromosome 4q showed that all affected family members were carriers of the risk haplotype (fig 2). Recombination between D4S1560 and D4S2966 was detected in affected individuals II-9 and III-15. Another recombination between D4S1613 and D4S1522 was found in affected individuals III-8 and IV-6. Most normal members of the family who were examined did not carry the haplotype. However, the genetically related normal individual II-11 carried a partial haplotype with a recombination between D4S1572 and D4S1570, suggesting that the candidate risk gene is located distal to D4S1572. Moreover, a genetically related normal individual, IV-2, carried the haplotype with a recombination between D4S1613 and D4S1522, where a recombination was detected in III-8 and IV-6. The results indicate that the candidate risk gene is located at the proximal side of D4S1522 (fig 2). Together, the haplotype between D4S1572 and D4S1522 cosegregates with the disease in this family. Thus a linkage of the RDC locus to a $15 \mathrm{cM}$ interval between D4S1572 and D4S1522 was established.

The genomic interval between D4S1572 and D4S1522 contains 65 known genes and 56 reference genes. Three potential candidate genes for RDC were chosen for further mutation examination, based on both their tissue specific expression and their roles in regulating cell proliferation, differentiation, and migration that may play an important part in RDC pathogenesis. ${ }^{2}$ These include IDAX (NM 025212), ${ }^{3}$ TM4SF9 (NM005723), ${ }^{4}$ and PITX2 (NM 153427). ${ }^{5}$ Mutation analysis showed no mutations in IDAX or TM4SF9 
T T T C CA G AG G A AC C GC T AC C C G G ACATC

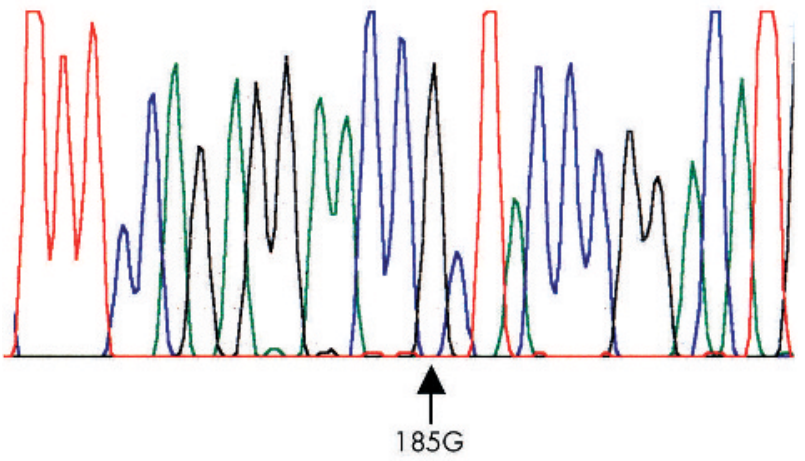

T T TC CAG AGG A AC CNC TAC C CGG ACAT

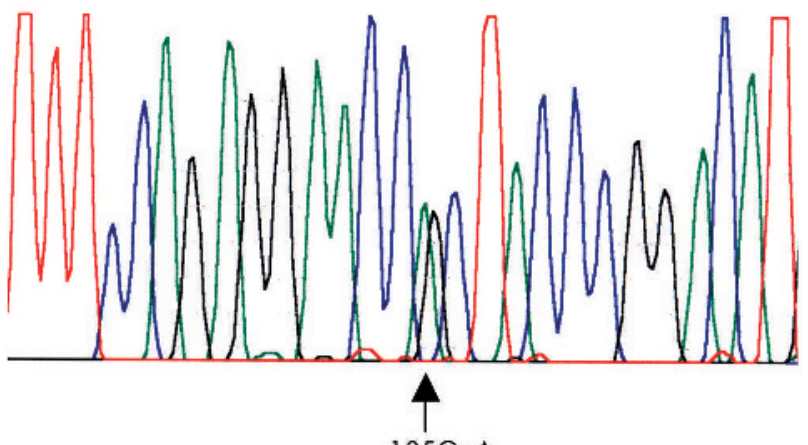

$185 \mathrm{G}>\mathrm{A}$

T T T C CAGAGGAAC CAC TAC C C G G ACAT

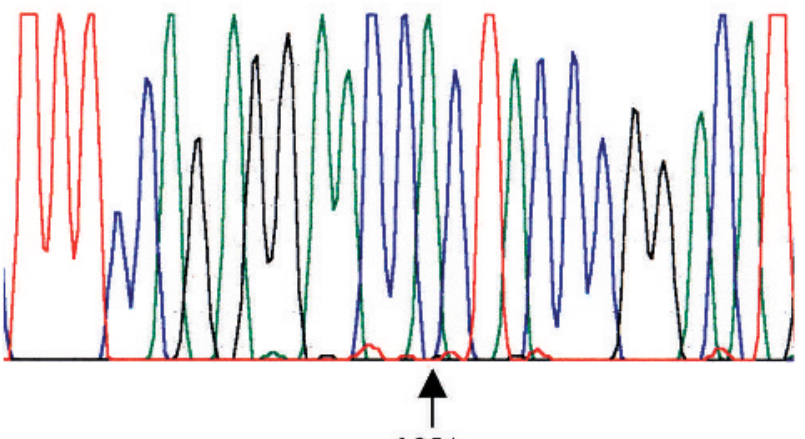

$185 \mathrm{~A}$

Figure 3 Partial sequence chromatographs of PITX2. Normal PITX2 $185 \mathrm{G}$ (upper panel), the heterozygous missense mutation $185 \mathrm{G} \rightarrow \mathrm{A}$ identified in all patients except patient III- 12 (middle panel), and a homozygous mutation $185 \mathrm{G} \rightarrow \mathrm{A}$ identified in patient III- 12 (lower panel) are shown.

of the proband. A heterozygous mutation of guanine to adenine $(185 \mathrm{G} \rightarrow \mathrm{A})$ was detected in PITX2 of the proband (fig 3). Further sequence analysis showed a perfect segregation of this mutation with the disease in all 17 affected individuals in the family. Interestingly, affected individual III-12 showed a homozygous mutation. The mother of III-12 is an affected person harbouring a heterozygous G185A mutation, while the father is normal, with no mutation at nucleotide 185. Genetic analysis confirms that the father is the biological father (not shown). It is likely that III-12 carries a mutation inherited from the mother and a de novo mutation at the same position. No mutation of PITX2 was detected in eight genetically related normal individuals, seven genetically unrelated individuals in the family, and 150 ethnically appropriate normal controls. The results indicate that the sequence change observed is not a common polymorphism.

\section{COMMENT}

PITX2, a downstream target of wnt/ $\beta$-catenin pathway, encodes a homeodomain transcription factor required for normal development of multiple organs, including eye, heart, and pituitary. ${ }^{6-13}$ Mutations in PITX2 are associated with multiple dominantly inherited diseases related to malfunction of the eyes, including Riger syndrome, ${ }^{5}$ iridogoniodysgenesis, ${ }^{14}$ iris hypoplasia, ${ }^{15}$ and Peter's anomaly. ${ }^{16}$ This study suggests that mutation in PITX2 is linked to another eye disease. The PITX2 G185A mutation found in RDC patients is a novel disease associated mutation resulting in a substitution of arginine by histidine at amino acid $62(\mathrm{R} 62 \mathrm{H})$ located in the conserved DNA binding homeodomain (fig 4). The mutation probably results in changes in its transcriptional activity, as with other disease associated mutations identified in this gene. ${ }^{17-21}$ Identification of this novel mutation in PITX2 may reveal the molecular mechanism underlying the RDC pathology.

\section{ACKNOWLEDGEMENTS}

This study was supported by Chinese 973 projects (G1998051002 and 2001CB510302), 863 projects (2002BA711A07-08,03, Z19-02-02-02, 2001AA227011, and 2002BA711A08), the Chinese National Natural Science Foundation (39980018, 30070410, 30270735, and 30340078), the Cheung Kong Scholars Programme, and the Life Science Research Foundation of Hunan Province.

\section{Authors' affiliations}

K Xia, L Wu, X Liu, D Liang, D Zheng, F Cai, Q Pan, Z Long, H Dai, Z Hu, Z Zhang, J Xia, National Laboratory of Medical Genetics of China, Central South University, Changsha, Hunan, China

$\mathbf{X ~ X i , ~ X i a n g y a ~ 2 n d ~ H o s p i t a l , ~ C e n t r a l ~ S o u t h ~ U n i v e r s i t y ~}$

B Tang, Xiangya Hospital, Central South University

Conflicts of interest: none declared

Correspondence to: Dr K Xia, National Laboratory of Medical Genetics of China, Central South University, Changsha, Hunan, China; nlmglcy@ xysm.net

\section{REFERENCES}

1 Xia JH, Yang YF, Deng $H$, Tang BS, Tang DS, He YG, Xia K, Chen SX, Li YX, Pan Q, Long ZG, Dai HP, Liao XD, Xiao JF, Liu ZR, Lu CY, Yu KP, Deng HX. Identification of a locus for disseminated superficial actinic porokeratosis at chromosome 12q23.2-24.1. J Invest Dermatol 2000;1 14:1071-4.

2 Mattos J, Contreras F, O'Donnell FE. Ring dermoid syndrome. A new syndrome of autosomal dominantly inherited, bilateral, annular limbal dermoids with corneal and conjunctival extension. Arch Ophthalmol 1980;98:1059-61.

3 Hino S, Kishida S, Michive T, Fukui A, Sakamoto I, Takada S, Asashima M, Kikuchi A. Inhibition of the Wnt signaling pathway by Idax, a novel Dvlbinding protein. Mol Cell Biol $2001 ; 21: 330-42$.

4 Todd SC, Doctor VS, Levy S. Sequences and expression of six new members of the tetraspanin/TM4SF family. Biochim Biophys Acta 1998;1399:101-4.

5 Semina EV, Reiter R, Leysens NJ, Alward WL, Small KW, Datson NA, SiegelBartelt J, Bierke-Nelson D, Bitoun P, Zabel BU, Carey JC, Murray JC. Cloning and characterization of a novel bicoid-related homeobox transcription factor gene, RIEG, involved in Rieger syndrome. Nat Genet 1996;14:392-9.

6 Gage PJ, Suh H, Camper SA. Dosage requirement of Pitx 2 for development of multiple organs. Development 1999;126:4643-51.

7 Baek SH, Kioussi C, Briata P, Wang D, Nguyen HD, Ohgi KA, Glass CK, Wynshaw-Boris A, Rose DW, Rosenfeld MG. Regulated subset of Gl growthcontrol genes in response to derepression by the Wnt pathway. Proc Natl Acad Sci USA 2003;100:3245-50.

8 Briata P, llengo C, Corte G, Moroni C, Rosenfeld MG, Chen CY, Gherzi R. The Wnt/beta-catenin $\rightarrow$ Pitx2 pathway controls the turnover of Pitx2 and other unstable mRNAs. Mol Cell 2003;12:1201-11.

9 Clevers H. Inflating cell numbers by Wnt. Mol Cell 2002;10:1260-1.

10 Kioussi C, Briata P, Baek SH, Rose DW, Hamblet NS, Herman T, Ohgi KA, Lin C, Gleiberman A, Wang J, Brault V, Ruiz-Lozano P, Nguyen HD, Kemler R, Glass CK, Wynshaw-Boris A, Rosenfeld MG. Identification of a Wnt/Dvl/ beta-Catenin $\rightarrow$ Pitx 2 pathway mediating cell-type-specific proliferation during development. Cell 2002;111:673-85. 
Table 1 Two point LOD scores between the disease gene and 14 markers of chromosome 4q22-q26

\begin{tabular}{|c|c|c|c|c|c|c|c|c|}
\hline \multirow[b]{2}{*}{ Locus } & \multirow[b]{2}{*}{ Genetic distance† } & \multicolumn{5}{|c|}{ LOD SCORE AT $\theta=*$} & \multirow[b]{2}{*}{$Z_{\max }$} & \multirow[b]{2}{*}{$\theta_{\text {max }}$} \\
\hline & & 0.0 & 0.1 & 0.2 & 0.3 & 0.4 & & \\
\hline D4S1560 & 104.75 & -2.50 & 1.25 & 1.17 & 0.86 & 0.45 & 1.25 & 0.1 \\
\hline D4S2966 & 106.89 & 3.41 & 2.87 & 2.26 & 1.57 & 0.81 & 3.41 & 0 \\
\hline D4S1572 & 107.95 & 3.91 & 3.41 & 2.72 & 1.88 & 0.93 & 3.91 & 0 \\
\hline D4S1570 & 109.02 & 3.58 & 2.98 & 2.31 & 1.56 & 0.73 & 3.58 & 0 \\
\hline D4S1564 & 112.62 & 6.07 & 5.04 & 3.90 & 2.66 & 1.30 & 6.07 & 0 \\
\hline D4S2945 & 116.37 & 5.04 & 4.21 & 3.30 & 2.27 & 1.11 & 5.04 & 0 \\
\hline D4S2989 & 117.06 & 6.72 & 5.64 & 4.44 & 3.09 & 1.55 & 6.72 & 0 \\
\hline D4S1616 & 117.06 & 5.01 & 4.33 & 3.47 & 2.43 & 1.21 & 5.01 & 0 \\
\hline D4S406 & 117.06 & 2.33 & 1.91 & 1.45 & 0.95 & 0.39 & 2.33 & 0 \\
\hline D4S193 & 117.06 & 6.07 & 5.08 & 3.97 & 2.74 & 1.35 & 6.07 & 0 \\
\hline D4S1613 & 121.61 & 6.63 & 5.57 & 4.38 & 3.05 & 1.53 & 6.63 & 0.1 \\
\hline D4S1522 & 123.13 & 0.64 & 3.93 & 3.31 & 2.38 & 1.21 & 3.93 & 0.1 \\
\hline D4S1612 & 124.45 & -3.79 & 1.85 & 1.59 & 1.14 & 0.60 & 1.85 & 0.1 \\
\hline D4S402 & 124.45 & -1.97 & 1.87 & 1.63 & 1.19 & 0.63 & 1.87 & 0.1 \\
\hline D4S427 & 124.45 & -3.69 & 1.40 & 1.19 & 0.76 & 0.32 & 1.40 & 0.1 \\
\hline
\end{tabular}

*LOD scores were calculated under an autosomal dominant mode of inheritance and a penetrance of $100 \%$.

†Sex averaged genetic distance from the next marker in centimorgans according to the Genethon human genetic linkage map (1996).

\author{
NM_153426-PITX2-VAR2 \\ MOUSE-NM_011098 \\ RAT-NM_019334 \\ NM_153427-PITX2-VAR1 \\ NM_000325-PITX2-VAR3 \\ Gallus \\ Danio \\ NM_002653-PITX1
}

NM_153426-PITX2-VAR2

MOUSE-NM_011098

RAT-NM_019334

NM_153427-PITX2-VAR1

NM_000325-PITX2-VAR3

Gallus

Danio

NM_002653-PITX1
KEAASSKFFPRQHPGANEKDKSQQGKNEDVGAEDPSKKKRQRRQRTHFTSQQLQELEATF 104 KESASSKLFPRQHPGANEKDKGQQGKNEDVGAEDPSKKKRQRRQRTHFTSQQLQELEATF 104 -------------EKDKGQQGKNEDVGAEDPSKKKRQRRQRTHFTSQQLQELEATF 58 ---------------EKDKSQQGKNEDVGAEDPSKKKRQRRQRTHFTSQQLQELEATF 58 HRLEVHTISDTSSPEAAEKDKSQQGKNEDVGAEDPSKKKRQRRQRTHFTSQQLQELEATF 111 HRLEVHTISDTSSPEAAEKEKSQQGKSEDAGPEDPSKKKRQRRQRTHFTSQQLQELEATF 120 HRLDVHTVSDTSSPESVEKEKGQS-KNEDSN-DDPSKKKRQRRQRTHFTSQQLQELEATF 101 ESSDTELPEKERGGEPKGPEDSGAGGTGCGGDDPPAKKKKQRRQRTHFTSQQLQELEATF 108

$$
\therefore \text {. . . }: * *: * * *: * * * * * * * * * * * * * * * * * * *
$$

QRNRYPDMSTREEIAVWTNLTEARVRVWFKNRRAKWRKRERNQQAELCKNGFGPQFNGLM 164 QRNRYPDMSTREEIAVWTNLTEARVRVWFKNRRAKWRKRERNQQAELCKNGFGPQFNGLM 164 QRNRYPDMSTREEIAVWTNLTEARVRVWFKNRRAKWRKRERNQQAELCKNGFGPQFNGLM 118 QRNRYPDMSTREEIAVWTNLTEARVRVWFKNRRAKWRKRERNQQAELCKNGFGPQFNGLM 118 QRNRYPDMSTREEIAVWTNLTEARVRVWFKNRRAKWRKRERNQQAELCKNGFGPQFNGLM 171 QRNRYPDMSTREEIAVWTNLTEARVRVWFKNRRAKWRKRERNQQAELCKNGFGPQFNGLM 180 QRNRYPDMSTREEIAVWTNLTEARVRVWFKNRRAKWRKRERNQQAELCKNGFGPQFNGLM 161 QRNRYPDMSMREEIAVWTNLTEPRVRVWFKNRRAKWRKRERNQQLDLCKGGYVPQFSGLV 168

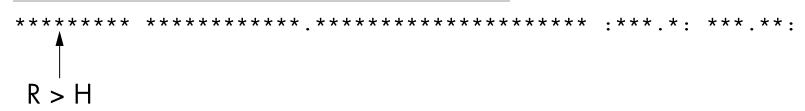

Figure 4 Sequence comparison of the homeodomain of human PITX2 and several proteins related to the homeodomain containing protein bicoid. The missense mutation $\mathrm{R} 68 \mathrm{H}$ in a conserved amino acid detected in patients with ring dermoid of the cornea is indicated.

11 Martin DM, Skidmore JM, Fox SE, Gage PJ, Camper SA. Pitx2 distinguishes subtypes of terminally differentiated neurons in the developing mouse neuroepithelium. Dev Biol 2002;252:84-99.

12 Martin DM, Skidmore JM, Philips ST, Vieira C, Gage PJ, Condie BG Raphael Y, Martinez S, Camper SA. PITX2 is required for normal development of neurons in the mouse subthalamic nucleus and midbrain. Dev Biol 2004;267:93-108.

13 Hsieh YW, Zhang XM, Lin E, Oliver G, Yang XJ. The homeobox gene Six3 is a potential regulator of anterior segment formation in the chick eye. Dev Biol 2002;248:265-80

14 Kulak SC, Kozlowski K, Semina EV, Pearce WG, Walter MA. Mutation in the RIEGl gene in patients with iridogoniodysgenesis syndrome. Hum Mol Genet 1998;7:1113-17.

15 Alward WL, Semina EV, Kalenak JW, Heon E, Sheth BP, Stone EM, Murray JC. Autosomal dominant iris hypoplasia is caused by a mutation in the Rieger syndrome (RIEG/PITX2) gene. Am J Ophthalmol 1998;125:98-100.
16 Doward W, Perveen R, Lloyd IC, Ridgway AE, Wilson L, Black GC. A mutation in the RIEG 1 gene associated with Peters' anomaly. J Med Genet 1999;36: 152-5.

17 Lines MA, Kozlowski K, Walter MA. Molecular genetics of Axenfeld-Rieger malformations. Hum Mol Genet 2002;11:1177-84.

18 Graw J. The genetic and molecular basis of congenital eye defects. Nat Rev Genet 2003;4:876-88.

19 Priston M, Kozlowski K, Gill D, Letwin K, Buys Y, Levin AV, Walter MA, Heon E. Functional analyses of two newly identified PITX2 mutants reveal a novel molecular mechanism for Axenfeld-Rieger syndrome. Hum Mol Genet 2001; 10:1631-8

20 Saadi I, Semina EV, Amendt BA, Harris DJ, Murphy KP, Murray JC, Russo AF. Identification of a dominant negative homeodomain mutation in Rieger syndrome. J Biol Chem 2001;276:23034-41.

21 Espinoza HM, Cox CJ, Semina EV, Amendt BA. A molecular basis for differential developmental anomalies in Axenfeld-Rieger syndrome. Hum Mol Genet 2002;11:743-53. 